BIOMEDICINE

\title{
Metabolic syndrome is inversely related to soluble receptor for advanced glycation end products: a study in mother-infant pairs
}

\author{
K. Klenovicsova', ${ }^{1,2}$ P. Boor ${ }^{3}$, J. Hrachova', K. Furkova', K. Sebekova ${ }^{4}$ \\ ${ }^{1}$ Slovak Medical University \\ 12, Limbova St., Bratislava, Slovak Republic, 83303 \\ ${ }^{2} 2^{\text {nd }}$ Department of Pediatrics, Faculty of Medicine, Comenius University \\ 1, Limbova St., Bratislava, Slovak Republic, 83340 \\ ${ }^{3}$ Division of Nephrology \& Institute of Pathology, RWTH University of Aachen \\ 30, Pauwelsstrabe, Aachen, Germany, 52074 \\ ${ }^{4}$ Institute of Molecular BioMedicine, Faculty of Medicine, Comenius University \\ 4, Sasinkova St., Bratislava, Slovak Republic, 81104 \\ kata.sebekova@gmail.com
}

\begin{abstract}
Aim. In the elderly subjects metabolic syndrome (MetS) seems to be associated with low levels of circulating protective soluble receptor for advanced glycation end products (sRAGE). This secondary study aimed to answer whether this phenomenon is manifested from early childhood. Methods. 73 mothers and their 77 infants (4-to-12-months of age) were included in the study. Mothers were classified according to the presence of MetS components as negative $(n=32)$, those with pre-MetS (insulin resistance +1 sign of MetS, $n=27)$ and overt MetS $(n=14)$. sRAGE and carboxymethyllysine $(C M L)$ were determined in the mothers and the infants. Results. Mothers with pre- and overt MetS displayed lower sRAGE levels, while in their children only a trend towards decline was observed. sRAGE levels significantly and inversely correlated with insulin sensitivity and BMI/body weight. No difference in CML levels across the groups was observed. Conclusions. Metabolic syndrome is associated with decreased levels of SRAGE in the mothers and a tendency towards decline of sRAGE in their offspring. Infants of mothers with MetS maintain normoglycemia on the account of higher insulin levels.
\end{abstract}

Keywords: metabolic syndrome, mother-child pairs, QUICKI, sRAGE, insulin resistance, CML.

Introduction. Advanced glycation end products (AGEs) are formed by nonenzymatic glycation/glyoxidation on plasma/tissue proteins during ageing and in accelerated degree under pathologic conditions (hyperglycemia, increased oxidative stress) [1,2]. AGEs alter the structure and function of proteins, and interact with their specific cell surface receptors. Receptor for AGEs (RAGE) is of pathophysiological importance: AGE/ RAGE interaction results in increased expression of

(C) Institute of Molecular Biology and Genetics NAS of Ukraine, 2011 cytokines, adhesion molecules, growth factors, and induction of oxidative stress [3, 4]. Circulating soluble RAGE (sRAGE) represents a truncated form of RAGE, consisting of only extracellular ligand binding domain. It acts as a natural competitive inhibitor of signaling pathways, removing or neutralizing the circulating RAGE ligands [5].

Several studies suggested a direct role of accumulated AGEs in pathogenesis of diabetes and its complications $[3,4]$. Recently, the role of low circulating sRAGE levels and their association with higher inci- 
dence of hypertension and metabolic syndrome (MetS) was highlighted [6-9].

Nowadays MetS is an epidemics, affecting all generations. It is considered a pre-diabetic state with prognosis of cardiovascular disease equivalent to type 2 diabetes [10]. Although the available definitions of MetS differ by criteria [11], visceral obesity and insulin resistance are unequivocally considered the major determinants in its development. Which of these two is the primary abnormality is still a debate.

The prevalence of MetS is highly age-dependent $[12,13]$. Studies on the association of MetS and sRAGE levels in the adult and elderly subjects showed that MetS is linked to low circulating sRAGE levels [7-9]. Therefore we raised the question, whether low sRAGE is per se associated with MetS, or merely represents an age-dependent feature. We postulated that if ageing is the main determinant of the above mentioned relation, this association would not be present in small infants, and probably not expressed significantly in young healthy adults. To this point we subjected the data obtained in frame of ICARE (Impeding neoformed Contaminants Accumulation to Reduce their health Effects) study from apparently healthy motherchild pairs to secondary analysis. ICARE clinical study aimed to elucidate the potential health effects of the consumption of low- (mother milk) versus high-AGE (infant formula) diets in healthy 3-to-18-month-olds infants [14]. Secondary aim was to study the motherchild relationship in AGE metabolism [15].

While published studies in adult and elderly subjects unequivocally confirm the association of MetS with low sRAGE levels [7-9], data on relation of single components of MetS to sRAGE are contradictory. Herein we analyzed sRAGE levels in the mothers not presenting any sign of MetS, and insulin resistant mothers with pre-metabolic- and overt metabolic-syndrome. To elucidate the impact of AGE/ RAGE axis, we determined plasma $\mathrm{N}^{\varepsilon}$-(carboxymethyl)lysine (CML, most abundant plasma AGE and a circulating ligand of RAGE) concentrations. Associations between single components of MetS and sRAGE or CML levels were determined. The same analyses were carried out in 4-to 12-month-olds infants.

Material and methods. The study was carried out according to the Declaration of Helsinki, after the ap- proval of the protocol by the Ethics Board of Slovak Medical University. Written informed consent from the mothers/legal representatives of the children was obtained.

Subjects. As described earlier [15], blood samples were obtained from 112 apparently healthy mothers and their 116 healthy infants. Exclusion criteria for infants were: pathology during physical examination, elevated inflammatory markers, acute/recurrent inflammatory or chronic diseases, and positivity for antibodies against HCV/HIV. Exclusion criteria for mothers were: age bellow 18 years, pregnancy, any ongoing disease and/or medication apart from food supplements, addiction to drugs, excessive smoking and/or alcohol consumption. The following criteria were used to classify the signs of MetS in the mothers: insulin resistance (QUICKI < 0.357) [16], body mass index $(\mathrm{BMI})>25.0 \mathrm{~kg} / \mathrm{m}^{2}$; triacylglycerols $(\mathrm{TAG}) \geq$ $\geq 1.7 \mathrm{mmol} / 1$; HDL-cholesterol $<1.3 \mathrm{mmol} / \mathrm{l}$; systolic blood pressure $(\mathrm{SBP}) \geq 130 \mathrm{~mm} \mathrm{Hg}$ and/or diastolic blood pressure (DBP) $\geq 85 \mathrm{~mm} \mathrm{Hg}$. BMI instead of waist circumference was used to classify the overweight/obesity, since cut off values of waist circumference for breast feeding mothers few weeks/months post partum are not published. Mother-child pairs were included into the evaluation if: a) mother and child met the inclusion criteria; $b$ ) data essential for classification of all 5 signs of MetS in the mother were obtained. In total, 73 healthy mothers and their 77 healthy infants (age range 4-12 months) were included into the evaluation. Thirty-two mothers did not display any sign of MetS. Insulin resistant mothers were further classified as those with pre-MetS (insulin resistance plus positivity for any 1 sign of MetS, $n=27$ ) and those with overt MetS (insulin resistance plus positivity for any 2 or more signs, $n=14$ ). Infants were grouped as offsprings of mothers not presenting any sign of MetS, those with pre- or overt MetS.

Blood was collected after overnight fasting from the mothers. Mothers were asked not to feed the babies 3 hours prior to blood sampling. Standard blood chemistry parameters (Vitros 250 analyzer, «J\&J», USA) were determined. Very low density lipoprotein (VLDL)- and low density lipoprotein (LDL)-cholesterol concentrations were calculated (Friedewald formula). Plasma was stored for special analysis at $-80^{\circ} \mathrm{C}$. 
Table 1

Characteristic of the study sample of 77 infants

\begin{tabular}{l|cc|c|c}
\hline \multirow{2}{*}{ Parameter } & \multicolumn{3}{c|}{ Classification of the mother } & \\
\cline { 2 - 4 } & Negative $(n=35)$ & Pre-MetS $(n=28)$ & $\mathrm{p}$ & $\mathrm{nstS}(n=14)$ \\
Age (months) & $6.7 ; 7.4 \pm 2.0$ & $8.0 ; 7.9 \pm 2.1$ & $6.3 ; 7.0 \pm 2.1$ & $\mathrm{~ns}$ \\
Gender (Female/Male) & $17 / 18$ & $14 / 14$ & $5 / 9$ & $\mathrm{~ns}$ \\
Birth weight, g & $3200 ; 2922 \pm 845$ & $3350 ; 3134 \pm 827$ & $3410 ; 3382 \pm 645$ & $\mathrm{~ns}$ \\
Body weight, g & $7800 ; 7813 \pm 1186$ & $7690 ; 7911 \pm 1513$ & $7705 ; 7837 \pm 940$ & $\mathrm{~ns}$ \\
$\begin{array}{l}\text { Duration of breast-feedin,g } \\
\text { (months) }\end{array}$ & $6.0 ; 6.4 \pm 2.0$ & $6.0 ; 5.6 \pm 3.0$ & $5.0 ; 5.3 \pm 3.3$ & \\
$\begin{array}{l}\text { Breast-/formula-feeding at } \\
\text { time of investigation, } n\end{array}$ & $26 / 9$ & $14 / 14$ & $8 / 6$ & $\mathrm{~ns}$ \\
\hline
\end{tabular}

Negative: mother without any sign of metabolic syndrome; pre-MetS: insulin resistant mother with 1 other sign of metabolic syndrome; MetS: overt metabolic syndrome; ns: not significant; chi: chi-square.

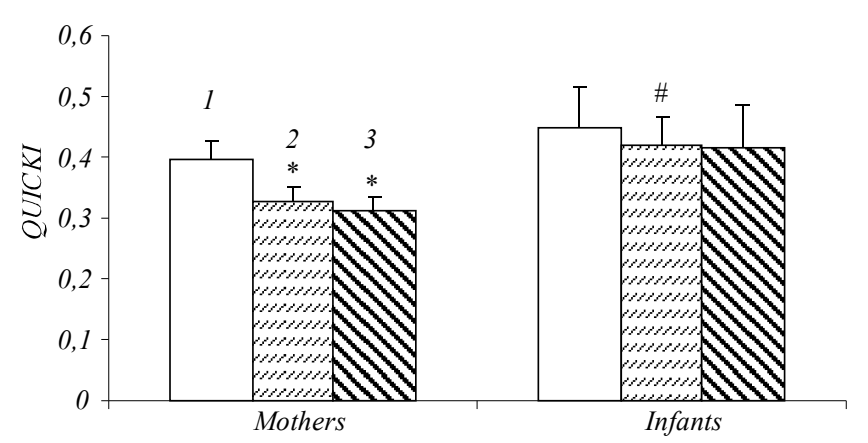

Fig. 1. Quantitative insulin-sensitivity check index (QUICKI) in the mothers and their infants in relation to presence of signs of metabolic syndrome: 1 - negative: no sign of metabolic syndrome in the mother; 2 - pre-MetS: insulin resistant mothers with any 1 other sigh of metabolic syndrome present; 3 - MetS: mothers with overt metabolic syndrome (insulin resistance plus any other 2 or more signs of metabolic syndrome). $* \mathrm{p}>0.01 ; \# \mathrm{p}>0.05$

Immunoreactive insulin was determined by RIA method («Immunotech», Czech Republic). Quantitative insulin-sensitivity check index (QUICKI) was calculated [17]. Commercial ELISA kits were used to determine plasma concentrations of sRAGE ( $\ll$ R\&D Systems Inc.», USA), and CML («MicroCoat Biotechnologie $\mathrm{GmbH}$ », Germany, after pre-treatment of the samples with proteinase $\mathrm{K}$ ). In the mothers, blood pressure was recorded after 15 min rest in sitting position. For technical reasons blood pressure and BMI were not recorded in the infants.

Statistical analyses. Data were tested for normality and equality of variance (Statistical program SPSS 16). Data were compared using One way analysis of varian- ce (ANOVA) with post-hoc least square difference test (LSD), or Kruskal-Wallis test with Mann-Whitney test (2-tailed), as appropriate. Spearman or Pearson correlation coefficients were calculated. Chi-square was used to compare categorical data. Data are given as median, mean \pm SD. $p<0.05$ was considered as significant.

Results and discussion. Cohort characteristics. M o t h e r s: 32 mothers negative for any sign of MetS did not differ significantly by age $(29.5 ; 29.5 \pm 3.8$ years) from those with pre-MetS $(27.0 ; 27.7 \pm 5.1$ years; $n=27)$ or those with overt MetS $(31.5 ; 30.8 \pm 7.3$ years, $n=14$ ). Four mothers delivered twins: 3 from the group negative for signs of MetS and 1 from the pre-MetS groups.

I $n$ f a $n t s:$ Characteristics of the infants are given in Table 1. Infants of the mothers negative for signs of MetS, those with pre-MetS and with overt MetS did not differ significantly by age and body weight at investigation, birth weight and the mean time of their exclusive breast-feeding. At the time of the investigation the proportion of the breast- versus formula-fed infants did not differ significantly between the groups. Both genders were comparably represented in the 3 cohorts.

Characteristics according to presence of signs of metabolic syndrome. M o t h e r s: Data on different components of MetS in the mothers negative for signs of MetS, those with pre- and overt MetS are given in Fig. 1 and Table 2. Mothers with overt MetS differed significantly in all parameters from the negative cohort. If compared with the negative mothers, those with pre- 
Clinical characteristics of the mothers and their infants

\begin{tabular}{|c|c|c|c|c|c|c|c|c|}
\hline \multirow{3}{*}{ Parameter } & \multicolumn{4}{|c|}{ Mothers } & \multicolumn{4}{|c|}{ Infants } \\
\hline & \multirow{2}{*}{$\begin{array}{l}\text { Negative } \\
(n=32)\end{array}$} & \multirow{2}{*}{$\begin{array}{c}\text { Pre-MetS } \\
(n=27)\end{array}$} & \multirow{2}{*}{$\begin{array}{l}\text { MetS } \\
(n=14)\end{array}$} & \multirow[b]{2}{*}{$\mathrm{p}$} & \multicolumn{3}{|c|}{ Classification of the mother } & \multirow[b]{2}{*}{$\mathrm{p}$} \\
\hline & & & & & Negative $(n=35)$ & $\begin{array}{c}\text { Pre-MetS } \\
(n=28)\end{array}$ & $\begin{array}{l}\text { MetS } \\
(n=14)\end{array}$ & \\
\hline BMI, $\mathrm{kg} / \mathrm{m}^{2}$ & $\begin{array}{c}20.5 \\
21.0 \pm 1.9\end{array}$ & $\begin{array}{c}22.2 \\
22.3 \pm 2.3\end{array}$ & $\begin{array}{c}29.4 \\
29.7 \pm 4.8 * *\end{array}$ & 0.01 & ND & ND & ND & NA \\
\hline $\mathrm{SBP}, \mathrm{mm} \mathrm{Hg}$ & $\begin{array}{c}118 \\
113 \pm 10\end{array}$ & $\begin{array}{c}120 \\
115 \pm 8\end{array}$ & $\begin{array}{c}123 \\
123 \pm 12 * *\end{array}$ & 0.01 & ND & ND & ND & NA \\
\hline $\mathrm{DBP}, \mathrm{mm} \mathrm{Hg}$ & $\begin{array}{c}70 \\
72 \pm 8\end{array}$ & $\begin{array}{c}80 \\
75 \pm 8\end{array}$ & $\begin{array}{c}80 \\
78 \pm 12^{+}\end{array}$ & 0.05 & ND & ND & ND & NA \\
\hline Glucose, $\mathrm{mmol} / 1$ & $\begin{array}{c}4.3 \\
4.4 \pm 0.6^{*}\end{array}$ & $\begin{array}{c}4.8 ; \\
4.9 \pm 0.6\end{array}$ & $\begin{array}{c}4.8 \\
4.8 \pm 0.7\end{array}$ & 0.05 & $\begin{array}{c}4.6 \\
4.5 \pm 0.4\end{array}$ & $\begin{array}{c}4.3 ; \\
4.4 \pm 0.4\end{array}$ & $\begin{array}{c}4.4 \\
4.4 \pm 0.5\end{array}$ & ns \\
\hline Insulin, IU/ml & $\begin{array}{c}4.6 \\
4.5 \pm 1.6^{* *}\end{array}$ & $\begin{array}{c}12.7 \\
16.1 \pm 10.2\end{array}$ & $\begin{array}{c}16.2 \\
21.2 \pm 15.5\end{array}$ & 0.01 & $\begin{array}{c}2.1 \\
3.0 \pm 2.4\end{array}$ & $\begin{array}{c}3.2 \\
3.8 \pm 2.4\end{array}$ & $\begin{array}{c}4.2 \\
5.6 \pm 5.6^{+}\end{array}$ & 0.05 \\
\hline $\mathrm{TAG}, \mathrm{mmol} / \mathrm{l}$ & $\begin{array}{c}0.64 \\
0.72 \pm 0.27\end{array}$ & $\begin{array}{c}0.80 \\
0.91 \pm 0.31\end{array}$ & $\begin{array}{c}1.23 \\
1.45 \pm 0.69^{* *}\end{array}$ & 0.05 & $\begin{array}{c}1.27 \\
1.45 \pm 0.68\end{array}$ & $\begin{array}{c}1.27 \\
1.37 \pm 0.69\end{array}$ & $\begin{array}{c}1.66 \\
1.75 \pm 0.78\end{array}$ & $\mathrm{~ns}$ \\
\hline Cholesterol, mmol/1 & $\begin{array}{c}4.4 ; \\
4.3 \pm 0.6\end{array}$ & $\begin{array}{c}4.5 ; \\
4.6 \pm 0.8\end{array}$ & $\begin{array}{c}4.6 \\
4.6 \pm 1.0\end{array}$ & ns & $\begin{array}{c}3.7 \\
3.8 \pm 0.8\end{array}$ & $\begin{array}{c}3.4 \\
3.4 \pm 0.7\end{array}$ & $\begin{array}{l}3.6 \\
3.5 \pm 0.6\end{array}$ & ns \\
\hline $\begin{array}{l}\text { HDL-cholesterol, } \\
\mathrm{mmol} / \mathrm{l}\end{array}$ & $\begin{array}{c}1.70 \\
1.75 \pm 0.31\end{array}$ & $\begin{array}{c}1.60 \\
1.61 \pm 0.40\end{array}$ & $\begin{array}{c}1.10 \\
1.16 \pm 0.22^{* *}\end{array}$ & 0.01 & $\begin{array}{c}1.00 \\
1.04 \pm 0.27\end{array}$ & $\begin{array}{c}1.10 \\
1.09 \pm 0.31\end{array}$ & $\begin{array}{c}0.95 \\
1.01 \pm 0.17\end{array}$ & ns \\
\hline Uric acid, mmol/1 & $\begin{array}{c}225 \\
238 \pm 52\end{array}$ & $\begin{array}{c}221 ; \\
235 \pm 46\end{array}$ & $\begin{array}{c}299 \\
322 \pm 98 * *\end{array}$ & 0.01 & $\begin{array}{c}178 \\
181 \pm 41\end{array}$ & $\begin{array}{c}188 \\
190 \pm 55\end{array}$ & $\begin{array}{c}191 \\
191 \pm 62\end{array}$ & ns \\
\hline CML/sRAGE, ng/pg & $\begin{array}{c}0.56 \\
0.62 \pm 0.26\end{array}$ & $\begin{array}{c}0.60 \\
0.72 \pm 0.38\end{array}$ & $\begin{array}{c}0.81 \\
0.76 \pm 0.39^{+}\end{array}$ & 0.05 & $\begin{array}{c}0.48 \\
0.56 \pm 0.37\end{array}$ & $\begin{array}{c}0.51 \\
0.66 \pm 0.40\end{array}$ & $\begin{array}{c}0.59 \\
0.68 \pm 0.30\end{array}$ & ns \\
\hline
\end{tabular}

BMI: body mass index; SBP: systolic blood pressure; DBP: diastolic blood pressure; IU: international units; TAG: triacylglycwerols; HDL: high density lipoproteins; CML: $\mathrm{N}^{\varepsilon}$ (carboxymethyl)lysine; sRAGE: soluble receptor for advanced glycation end products; ND: not determined; NA: not applicable; ns: not significant; ${ }^{*} \mathrm{p}<0.05$ vs. both other groups; ${ }^{* *} \mathrm{p}<0.01$ vs. both other groups; ${ }^{+} \mathrm{p}<0.05$ vs. group negative for signs of metabolic syndrome.

MetS displayed significantly higher insulin resistance. Except for insulin sensitivity and diastolic blood pressure mothers with pre-MetS did not differ significantly from those with overt MetS.

In fan t s: Infants of the mothers negative for signs of MetS were significantly more insulin sensitive in comparison with the other 2 groups (Fig. 1 and Table $2)$. However, the infants' groups did not differ significantly by the body weight (Table 1), TAG, HDLcholesterol and uric acid concentrations (Table 2).

Advanced glycation end products and sRAGE. $\mathrm{M}$ o t h e r s: Concentration of CML was significantly higher in the mothers negative for signs of MetS if compared with those with overt MetS (Fig. 2,a). sRAGE levels were significantly lower in the mothers with overt MetS in comparison with other 2 groups
(Fig. 2, b). CML/sRAGE ratio increased across the groups reaching significance between the negative mothers and those with overt MetS (Table 2).

If all mothers were evaluated together, sRAGE levels directly correlated with the index of insulin sensitivity ( $<<0.001$ ) (Fig. 3), while inverse relationship between CML or sRAGE and BMI was observed ( $\mathrm{p}<0.01$ and $\mathrm{p}<0.001$, respectively), (Fig. 4, $a-b$ ). Simple correlation coefficients between sRAGE or CML and parameters characterizing MetS are given in Table 3. Following significant relationships were revealed: systolic and diastolic blood pressure, insulin and uric acid concentrations correlated inversely with sRAGE concentrations, while QUICKI or HDL-cholesterol concentration correlated with sRAGE directly. Inverse relationship was revealed between systolic blo- 

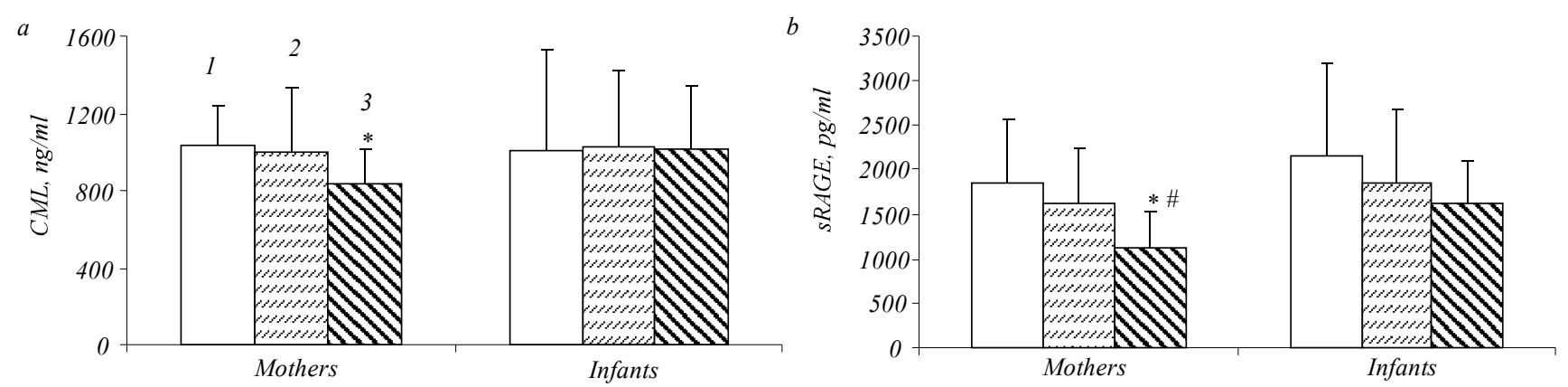

Fig. 2. $a$-plasma $\mathrm{N}^{\varepsilon}$ (carboxymethyl)lysine (CML) concentration in the mothers and their infants in relation to presence of signs of metabolic syndrome; $b$ - plasma soluble receptor for advanced glycation end products (sRAGE) concentrations in the mothers and their infants in relation to presence of signs of metabolic syndrome: 1 - negative: no sign of metabolic syndrome in the mother; 2 - pre-MetS: insulin resistant mothers with any 1 other sigh of metabolic syndrome present; 3 -MetS: mothers with overt metabolic syndrome (insulin resistance plus any other 2 or more signs of metabolic syndrome). * p >0.01; \# p >0.05

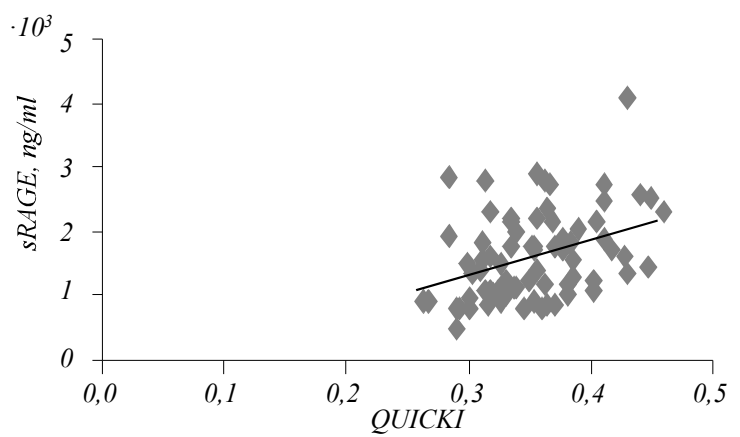

Fig. 3. Relationship between plasma soluble receptor for advanced glycation end products (sRAGE) concentrations and Quantitative insulin-sensitivity check index (QUICKI) in the mothers. $r=0.394$ $\mathrm{p}<0.001$

od pressure and plasma CML concentration. HDLcholesterol levels showed a direct relationship to CML concentration. Plasma CML levels did not correlate significantly with sRAGE levels.

Infants: CML concentrations were comparable between the infants' groups (Fig. 2, a). sRAGE concentration tended to decline and CML/sRAGE ratio to increase across the groups of the offsprings, without reaching significance (Fig. 2, $b$, Table 2). If all infants were evaluated together, sRAGE concentration was inversely related to actual body weight $(r=-0.23, \mathrm{p}<$ 0.05). CML levels and body weight or sRAGE concentrations showed no significant relationship. None of the other parameters characterizing MetS showed significant relation to CML or sRAGE concentration.

There are at least 2 splice variants of soluble RAGE capable to bind ligands and act as decoy receptors, since they possess a V- (ligand binding) domain [9]. While endogenous secretory RAGE (esRAGE) represents secreted C-terminally truncated isoform of RAGE,
sRAGE is cleaved from cell surface by matrix metalloproteinases $[8,9]$. Whether these isoforms differ in pathophysiological function remains unclear. However, the ELISA sRAGE assay used in present study measures all soluble forms of RAGE in human plasma [9]. In general population circulating sRAGE levels seem to be determined genetically. Carriers of minor allele in G82S RAGE gene polymorphism present with reduced levels of protective sRAGE, and this phenotype is manifested from early childhood [15, 18-20].

Herein we show that decline in sRAGE levels with increasing insulin resistance, previously described in the adults and elderly [7-9], is not merely an age-dependent phenomenon. This association is present already in the young women, and a same trend is observed in their offsprings. As in the adults [20-22], body weight and sRAGE show inverse relationship already in early infancy.

An inverse relationship between sRAGE levels and insulin sensitivity might be on the account of genetic predisposition in RAGE gene, affecting the development of insulin resistance or be in linkage disequilibrium with a locus involved in this process $[15,18$ 20]. Minor allele carriers in G82S RAGE gene polymorphism display reduced levels of protective sRAGE $[15,18-20]$. Young women bearing this allele display also insulin resistance [15]. It is sought that hyperglycemia could inhibit sRAGE production directly [7]. However, our mothers and infants were normoglycemic, and no significant relationship was observed between glycemia and sRAGE. Indirect inhibition of sRAGE production via AGEs [7] seems also to be im- 

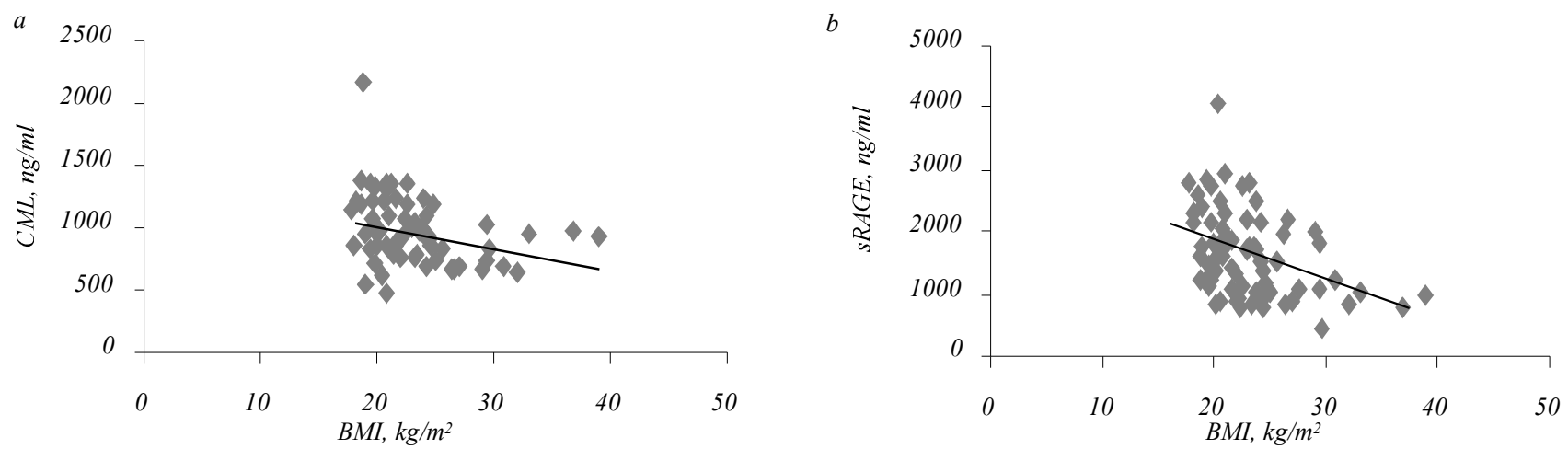

Fig. 4. $a$-relationship between plasma $\mathrm{N}^{\varepsilon}$ (carboxymethyl)lysine (CML) concentration and body mass index (BMI) in the mothers $r=0.329$; $\mathrm{p}<0.01 ; b-$ relationship between plasma soluble receptor for advanced glycation end products (sRAGE) concentrations and BMI in the mothers, $r=0.402 ; \mathrm{p}<0.001$

probable: mothers with overt MetS displayed lower CML levels than their insulin sensitive counterparts, and the infants' groups did not differ in CML levels. In neither cohort CML levels showed significant relationship to sRAGE or glycemia. Despite our findings that the infants of insulin resistant mothers showed only a tendency towards lower sRAGE levels in dependence of rising number of signs of MetS in the mothers, we suppose that decreased circulating levels of protective sRAGE are involved in the successive development of insulin resistance.

Here we also show an inverse association between sRAGE and several other components of MetS (e. g. blood pressure, insulin and uric acid levels) in young apparently healthy women. An inverse relationship between insulin sensitivity and sRAGE levels in healthy older adults and type 2 diabetic patients has been reported previously, but this study found no relationship between sRAGE and components of MetS in healthy subjects [7]. On the other hand, same associations as reported by us were described in older adults and type 2 diabetic patients for esRAGE [8].

In the mothers BMI showed the tightest (inverse) relationship to sRAGE. This finding is in line with data in Japanese non-diabetic adults and Korean men [2022]. Interestingly, the single significant relationship (inverse) in the infants was that between actual body weight and sRAGE level. Thus, body weight/obesity exerts significant impact on sRAGE levels from early childhood. Question arises whether obesity per se, or central obesity is of key importance.

Low plasma CML levels in the mothers with MetS corresponde with previous findings that obese children and adults display lower plasma CML levels than their lean counterparts [23,24]. In contrast to other AGEs, in obesity CML is predominantly trapped into adipose tissue [24]. Negative relationship between CML levels and BMI in our mothers supports this finding. This phenomenon seems to be expressed from early childhood, as in our infants CML levels showed inverse relationship to actual body weight.

To the best of our knowledge this is the first study investigating whether young infants of otherwise healthy insulin resistant mothers with signs of pre-MetS or overt MetS display corresponding metabolic disturbances. From among 41 mothers classified as insulin resistant (QUICKI $<0.357$ ) [16] only 3 displayed fasting glycemia $>5.6 \mathrm{mmol} / \mathrm{l}$, thus they were in early stages of insulin resistance, still capable to maintain fasting glycemia within normal (or almost normal) range on the account of hyperinsulinemia. Mothers with overt MetS presented only mild metabolic disturbances, e. g. they suffered from mild hypertension, mild insulin resistance, displayed mild dyslipidemic phenotype and their higher uric acid concentrations fall within the normal range. The more striking is the observation that their young offsprings maintain the normoglycemia at the expense of higher insulinemia.

It is well known that breast-fed toddlers are more insulin sensitive than their formula-fed counterparts [25]. This is believed to be due to lower protein and higher polyunsaturated fatty acids content of mother milk, higher immunogeneity of the cow insulin in comparison with human insulin in mother milk, and the presence of various insulin sensitizing compounds in mother milk [26-28]. On the other hand, infant formu- 
Table 3

Correlation coefficients between plasma Ne(carboxymethyl)lysine (CML) and soluble receptor for advanced glycation end products (sRAGE) concentrations and characteristics of metabolic syndrome

\begin{tabular}{|c|c|c|c|c|c|c|c|c|}
\hline \multirow{3}{*}{ Parameter } & \multicolumn{4}{|c|}{ CML } & \multicolumn{4}{|c|}{ sRAGE } \\
\hline & \multicolumn{2}{|c|}{ Mothers } & \multicolumn{2}{|c|}{ Infants } & \multicolumn{2}{|c|}{ Mothers } & \multicolumn{2}{|c|}{ Infants } \\
\hline & $r$ & $\mathrm{p}$ & $r$ & $\mathrm{p}$ & $r$ & $\mathrm{p}$ & $r$ & $\mathrm{p}$ \\
\hline Systolic BP & -0.30 & 0.05 & ND & ND & -0.32 & 0.01 & ND & ND \\
\hline Diastolic BP & -0.03 & ns & ND & ND & -0.31 & 0.01 & ND & ND \\
\hline Insulin & -0.02 & $\mathrm{~ns}$ & -0.15 & $\mathrm{~ns}$ & -0.29 & 0.05 & -0.15 & ns \\
\hline Glucose & -0.14 & ns & -0.10 & $\mathrm{~ns}$ & -0.20 & $\mathrm{~ns}$ & -0.02 & ns \\
\hline QUICKI & 0.23 & $\mathrm{~ns}$ & 0.07 & $\mathrm{~ns}$ & 0.40 & 0.001 & 0.12 & ns \\
\hline TAG & -0.03 & ns & -0.04 & ns & -0.21 & ns & 0.20 & ns \\
\hline HDL-cholesterol & 0.24 & 0.05 & 0.16 & $\mathrm{~ns}$ & 0.32 & 0.01 & 0.03 & ns \\
\hline Uric acid & -0.03 & ns & 0.19 & $\mathrm{~ns}$ & -0.27 & 0.05 & 0.19 & ns \\
\hline
\end{tabular}

BP: blood pressure; QUICKI: Quantitative insulin-sensitivity check index; TAG: triacylglycerols; HDL: high density lipoproteins; ND: not determined; ns: not significant.

las contain, due to their fortification, higher amounts of vitamins in comparison to mother milk. In middle-aged and elderly men higher total carotenoid intakes, mainly those of beta-carotene and lycopene, were associated with a lower prevalence of metabolic syndrome, and in adolescents and adults high plasma levels of carotenoids are associated with higher insulin sensitivity [2931]. The infants in our study did not differ significantly by age, they were breast-fed for comparable time, and the proportion of infants breast- or formula-fed at the time of investigation did not differ significantly. Thus, we suppose that other factors except for formula feeding may modulate insulin sensitivity in young infants.

Limitations of this study arise from the fact of secondary analysis of data gathered for other purposes, and cross-sectional approach. Relatively small number of included subjects reflects the fact that samples were collected from healthy mother-infant pairs for exclusively research purposes, thus mother's will to participate was decisive. The number of mothers in 3 groups was uneven.

However, it is to be taken into account that the prevalence of MetS is age-dependent. In Norway, $9.2 \%$ of 20-29-old women and $14.1 \%$ of those aged 30-39 years present with overt MetS [12]. Recent study from Slovakia reported the prevalence of MetS in general population being $4.3 \%$ in 18-to-29-year olds, and
$10.4 \%$ in the age category of 30 to 39 years [13]. Thus $19 \%$ of young mothers presenting with overt MetS in our study even slightly exceeds the average/ expected prevalence. However, we suppose that this follows from the design of the study (secondary analysis including only mothers in whom the data on all 5 signs of MetS were determined). Since we did not measure the blood pressure in the infants, we are not able to comment whether the blood pressure correlates with sRAGE or CML levels in early childhood.

Taken together, lower circulating sRAGE levels seem to be an early feature of insulin resistance and MetS-related disturbances, manifested already in young adult women. Infants of insulin resistant mothers with overt MetS maintain normoglycemia on the account of higher insulin demand, while the decline of their circulating sRAGE level does not reach significance yet. Decrease in sRAGE levels shows strongest relationship to rise in BMI or body weight. Our data support the assumption of the direct link between decreased circulating levels of protective sRAGE and the successive development of insulin resistance. However, the design of our study does not allow any conclusion in regard whether high sRAGE is a protective factor, or low sRAGE a causal factor in development of insulin resistance. To confirm our data larger and prospective studies are required. 


\section{Acknowledgement. Study was supported by EU $6^{\text {th }}$ FP grant ICARE No. COLL-CT-2005-516415.}

\section{К. Кленовічова, П. Бор, Я. Грахова, К. Фуркова, К. Шебекова}

Метаболічний синдром обернено асоційований 3 розчинним рецептором для кінцевих продуктів повного глікозилювання: вивчення пар мати-дитина

Резюме

Мета. У паиієнтів похилого віку розвиток метаболічного синдрому (МетС) асоиійований з низьким рівнем цииркулюючого розчинного рецептора для кінцевих продуктів повного глікозилювання (sRAGE). Мета иієї роботи полягала у пошуку відповіді на питання, чи проявляється таке явище у ранньому дитинстві? Методи. Досліджено 73 матері і 77 дітей віком від чотирьох до 12 місяиів. Залежно від присутності компонентів МетС матерів розділили на три групи: негативна $(n=32)-$ без компонентів МетC; з початковою стадією МетС (резистентність до інсуліну + одна ознака МетC, $n=27)$ та з явно вираженим МетC $(n=14)$. У матерів і дітей визначали рівень кониентрації sRAGE і карбоксиметиллізину (КМЛ). Результати. У матерів з початковою та явно вираженою стадіями МетС встановлено нижчий рівень sRAGE порівняно з їхніми дітьми, у яких спостерігали лише тендениію до його падіння. Кількість sRAGE корелює з чутливістю до інсуліну та показником ВM (індекс маси тіла) I/маса тіла. Різниці в концентрації КМЛ по групах не знайдено. Висновки. Метаболічний синдром пов' язаний із зниженням рівня $R R A G E$ у матерів. Показано тендениию до зменшення кількості sRAGE у їхніх дітей. Нормоглікемія у дітей, у матерів яких визначено МетС, підтримується вищим рівнем інсуліну.

Ключові слова: метаболічний синдром, пара мати-дитина, QUICKI, sRAGE, резистентність до інсуліну, карбоксиметиллізин.

\section{К. Кленовичова, П. Бор, Я. Грахова, К. Фуркова, К. Шебекова}

Метаболический синдром обратно ассоциирован с

растворимым рецептором для конечных продуктов полного гликозилирования: изучение пар мать-ребенок

\section{Резюме}

Цель. У пациентов пожилого возраста развитие метаболического синдрома (МетС) ассочиировано с низким уровнем ииркулирующего растворимого рецептора для конечных продуктов полного гликозилирования (sRAGE). Цель этой работы состояла в поиске ответа на вопрос, проявляется ли данное явление в раннем детстве? Методы. Исследованы 73 матери и 77 детей в возрасте от четырех до 12 месяиев. В зависимости от присутствия компонентов МетС матерей разделили на три группь: отрицательная $(n=32)$ - без компонентов МетС; с начальной стадией МетС (резистентность к инсулину + один признак MeтC, $n=27)$ и с явно выраженным МетC $(n=14)$. У матерей и детей определяли уровень концентрачии SRAGE и карбоксиметиллизина (КМЛ). Результаты. У матерей с начальной и явно выраженной стадиями МетС выявлен более низкий уровень $S R A G E$, в то время как у их детей наблюдалась лишь тенденция к его снижению. Количество sRAGE коррелирует с чувствительностью к инсулину и показателем ВМ (индекс массы тела) I/масса тела. Разницы в кониентрации КМЛ по группам не установлено. Выводы. Метаболический синдром связан со снижением уровня SRAGE у матерей. Показана тендениия к уменьшению количества SRAGE у их детей. Нормогликемия у детей, у матерей которых обнаружен МетС, поддерживается более высоким уровнем инсулина.

Ключевые слова: метаболический синдром, пара мать-ребенок, QUICKI, sRAGE, резистентность к инсулину, карбоксиметиллизин.

\section{REFERENCES}

1. Miyata T., Wada Y., Cai Z., Iida Y., Horie K., Yasuda Y., Maeda K., Kurokawa K., van Ypersele de Strihou C. Implication of an increased oxidative stress in the formation of advanced glycation end products in patients with end-stage renal failure // Kidney Int.-1997.-51, N 4.-P. 1170-1181.

2. Brownlee M., Cerami A., Vlassara H. Advanced glycosylation end products in tissue and the biochemical basis of diabetic complications // N. Engl. J. Med.-1988.-318, N 20.-P. 1315-1321.

3. Schmidt A. M., Yan S. D., Wautier J. L., Stern D. Activation of receptor for advanced glycation end products: a mechanism for chronic vascular dysfunction in diabetic vasculopathy and atherosclerosis // Circ. Res.-1999.-84, N 5.-P. 489-497.

4. Bierhaus A., Schiekofer S., Schwaninger M., Andrassy M., Humpert P. M., Chen J., Hong M., Luther T., Henle T., Kloting I., Morcos M., Hofmann M., Tritschler H., Weigle B., Kasper M., Smith M., Perry G., Schmidt A. M., Stern D. M., Haring H. U., Schleicher E., Nawroth P. P. Diabetes-associated sustained activation of the transcription factor nuclear factor-kappaB // Diabetes.-2001.-50, N 12.-P. 2792-2808.

5. Yonekura H., Yamamoto Y., Sakurai S., Petrova R. G., Abedin M. J., Li H., Yasui K., Takeuchi M., Makita Z., Takasawa S., Okamoto H., Watanabe T., Yamamoto H. Novel splice variants of the receptor for advanced glycation endproducts expressed in human vascular endothelial cells and pericytes, and their putative roles in diabetes-induced vascular injury // Biochem. J.-2003.-370, N 3.-P. 1097-1109.

6. Geroldi D., Falcone C., Emanuele E., D'Angelo A., Calcagnino M., Buzzi M. P., Scioli G. A., Fogari R. Decreased plasma levels of soluble receptor for advanced glycation end-products in patients with essential hypertension // J. Hypertens.-2005.-23, N 9.-P. 1725-1729.

7. Basta G., Sironi A. M., Lazzerini G., Del Turco S., Buzzigoli E., Casolaro A., Natali A., Ferrannini E., Gastaldelli A. Circulating soluble receptor for advanced glycation end products is inversely associated with glycemic control and S100A12 protein // J. Clin. Endocrinol. Metab.-2006.-91, N 11.-P. 4628-4634.

8. Koyama H., Shoji T., Yokoyama H., Motoyama K., Mori K., Fukumoto S., Emoto M., Shoji T., Tamei H., Matsuki H., Sakurai S., Yamamoto Y., Yonekura H., Watanabe T., Yamamoto H., Nishizawa $Y$. Plasma level of endogenous secretory RAGE is associated with components of the metabolic syndrome and atherosclerosis // Arterioscler. Thromb. Vasc. Biol.-2005.-25, N 12.-P. 2587-2593.

9. Koyama H., Yamamoto H., Nishizawa Y. Endogenous secretory RAGE as a novel biomarker for metabolic syndrome and cardiovascular diseases // Biomark. Insights.-2007.-2, N 1.-P. 331-339.

10. Wilson P. W., D'Agostino R. B., Parise H., Sullivan L., Meigs J. $B$. Metabolic syndrome as a precursor of cardiovascular disease 
and type 2 diabetes mellitus // Circulation.-2005.-112, N 20.P. 3066-3072.

11. Fulop T., Tessier D., Carpentier A. The metabolic syndrome // Pathol. Biol. (Paris).-2006.-54, N 7.- P. 375-386.

12. Hildrum B., Mykletun A., Hole T., Midthjell K., Dahl A. A. Agespecific prevalence of the metabolic syndrome defined by the International Diabetes Federation and the National Cholesterol Education Program: the Norwegian HUNT 2 study // BMC Public Health.-2007.-7.-P. 220.

13. Mokan M., Galajda P., Pridavkova D., Tomaskova V., Sutarik L., Krucinska L., Bukovska A., Rusnakova G. Prevalence of diabetes mellitus and metabolic syndrome in Slovakia // Diabetes Res. Clin. Pract.-2008.-81, N 2.-P. 238-242.

14. Sebekova K., Saavedra G., Zumpe C., Somoza V., Klenovicsova K., Birlouez-Aragon I. Plasma concentration and urinary excretion of $\mathrm{N}$ epsilon-(carboxymethyl)lysine in breast milk- and formula-fed infants // Ann. N. Y. Acad. Sci.-2008.-1126.P. $177-180$.

15. Boor P., Celec P., Klenovicsova K., Vlkova B., Szemes T., Minarik G., Turna J., Sebekova K. Association of biochemical parameters and RAGE gene polymorphisms in healthy infants and their mothers // Clin. Chim. Acta.-2010.-411, N 15-16.-P. 1034-1040.

16. Hrebicek J., Janout V., Malincikova J., Horakova D., Cizek $L$. Assessment and prevention detection of insulin resistance by simple quantitative insulin sensitivity check index QUICKI for epidemiological assessment and prevention // J. Clin. Endocri- nol. Metab.-2002.- 87, N 1.-P. 144-147.

17. Katz A., Nambi S. S., Mather K., Baron A. D., Follmann D. A., Sullivan G., Quon M. J. Quantitative insulin sensitivity check index: a simple, accurate method for assessing insulin sensitivity in humans // J. Clin. Endocrinol. Metab.-2000.-85, N 7.-P. 24022410 .

18. Sullivan C. M., Futers T. S., Barrett J. H., Hudson B. I., Freeman M. S., Grant P. J. RAGE polymorphisms and the heritability of insulin resistance: the Leeds family study // Diab. Vasc. Dis. Res.-2005.-2, N 1.-P. 42-44.

19. Gaens K. H. J., Ferreira I., van der Kallen C. J. H., van Greevenbroek M. M. J., Blaak E. E., Feskens E. J. M., Dekker J. M., Nijpels G., Heine R. J., 't Hart L. M., de Groot P. G., Stehouwer C. D. A., Schalkwijk C. G. Association of polymorphism in the receptor for advanced glycation end products (RAGE) gene with circulating RAGE levels // J. Clin. Endocrinol. Metab.2009.-94, N 12.-P. 5174-5180.

20. Jang Y., Kim J. Y., Kang S. M., Kim J. S., Chae J. S., Kim O. Y., Koh S. J., Lee H. C., Ahn C. W., Song Y. D., Lee J. H. Association of the Gly82Ser polymorphism in the receptor for advanced glycation end products (RAGE) gene with circulating levels of soluble RAGE and inflammatory markers in nondiabetic and nonobese Koreans // Metabolism.-2007.-56, N 2.- P. 199-205.

21. Yamagishi S., Adachi H., Nakamura K., Matsui T., Jinnouchi Y., Takenaka K., Takeuchi M., Enomoto M., Furuki K., Hino A., Shigeto Y., Imaizumi T. Positive association between serum levels of advanced glycation end products and the soluble form of receptor for advanced glycation end products in nondiabetic subjects // Metabolism.-2006.- 55, N 9.-P. 1227-1231.

22. Kim O. Y., Jo S. H., Jang Y., Chae J. S., Kim J. Y., Hyun Y. J., Lee J. H. G allele at RAGE SNP82 is associated with proinflammatory markers in obese subjects // Nutr. Res.-2009.-29, N 2.P. 106-113.

23. Sebekova K., Somoza V., Jarcuskova M., Heidland A., Podracka L. Plasma advanced glycation end products are decreased in obese children compared with lean controls // Int. J. Pediatr. Obes.2009.-4, N 2.-P. 112-118.

24. Gaens K. H. J., van de Waarenburg M. P. H., Nijhuis J., Scheijen J., Stehouwer C. D. A., Schalkwijk C. G. Increased formation of $\mathrm{N}^{\varepsilon}$ (carboxymethyl)lysine (CML) in human adipose tissue; possible biological consequences $/ / 9^{\text {th }}$ Int. Symp. on the Maillard Reaction (1-5 Sept., Munich, Germany).-Munich, 2007.-P. 64.

25. Owen C. G., Martin R. M., Whincup P. H., Smith G. D., Cook D. $G$. Does breastfeeding influence risk of type 2 diabetes in later life? A quantitative analysis of published evidence // Am. J. Clin. Nutr.-2006.-84, N 5.-P. 1043-1054.

26. Das $U . N$. The lipids that matter from infant nutrition to insulin resistance // Prostaglandins, Leukot. Essent. Fatty Acids.-2002.67, N 1.-P. 1-12.

27. Vaarala O., Knip M., Paronen J., Hamalainen A. M., Muona P., Vaatainen M., Ilonen J., Simell O., Akerblom H. K. Cow's milk formula feeding induces primary immunization to insulin in infants at genetic risk for type 1 diabetes // Diabetes.-1999.- 48, N 7.-P. 1389-1394.

28. Savino F., Fissore M. F., Liguori S. A., Oggero R. Can hormones contained in mothers' milk account for the beneficial effect of breast-feeding on obesity in children? // Clin. Endocrinol. (Oxf).-2009.-71, N 6.-P. 757-765.

29. Hozawa A., Jacobs D. R. Jr., Steffes M. W., Gross M. D., Steffen L. M., Lee D. H. Associations of serum carotenoid concentrations with the development of diabetes and with insulin concentration: interaction with smoking: the Coronary Artery Risk Development in Young Adults (CARDIA) study // Am. J. Epidemiol.-2006.163, N 10.-P. 929-937.

30. Sugiura M., Nakamura M., Ikoma Y., Yano M., Ogawa K., Matsumoto H., Kato M., Ohshima M., Nagao A. The homeostasis model assessment-insulin resistance index is inversely associated with serum carotenoids in non-diabetic subjects // J. Epidemiol.-2006.16, N 2.-P. 71-78.

31. Sluijs I., Beulens J. W., Grobbee D. E., van der Schouw Y. T. Dietary carotenoid intake is associated with lower prevalence of metabolic syndrome in middle-aged and elderly men // J. Nutr.-2009.139, N 5.-P. 987-992.

UDC $612.63+612.349 .8$ Received 2.01.2011 